\title{
Discussion about the Development Channels for Small and Micro Enterprises
}

\author{
QianHong Li \\ Harbin Engineering University, Finance Science, Harbin, China, 150000
}

\begin{abstract}
Keywords: Small and Micro Business, Crisis, Development Suggestions
Abstract. Small and micro enterprises are an important force for the economic and social development, and play an important role in providing employment, increasing the national fiscal revenues, etc., but influenced by the international financial crisis and complex and volatile economic situations at home and abroad, China's small and micro enterprises are faced with some new difficulties and challenges. The paper, by analyzing the current issues of China's small and micro business and based on some successful experience, makes the suggestions for promoting the benign development of the small and micro businesses.
\end{abstract}

\section{Issues of Small and Micro Businesses}

The Financing Difficulties Are More Prominent. Small and micro businesses often have fewer and unstable self-owned funds, cannot provide enough mortgage money, have poor innovation consciousness, etc., all of which make banks and other financial institutions be unwilling to provide loans to them. The reduction in the credit scale in recent years makes it more difficult for them to raise funds. Firstly, the financing cost is high. The loans for small and micro businesses have the "short-term, urgently-needed and frequent" characteristics. As the loan processing is cumbersome and the loan fee is high, banks universally increase theloan interest rates for the small and micro businesses by $50 \%$. Secondly, China's imperfect financial system causes fewer financing channels for small and micro businesses.[1]

The Increase of Uncertain Factors in the International and Domestic Markets Influence the Export of Small and Micro Businesses. The influences from financial crisis continue. Many small and micro textile, machinery processing enterprises export to foreign countries and other coastal provinces but have no core technologies, the sluggish foreign markets make many small and micro domestic processing trade enterprises into dilemma and suffer from heavy blows. According to related data, influenced by the financial crisis, textile enterprises are subjected to the most obvious impacts, many of them have to greatly lower the prices due to the substantial decrease in orders.

"Employment Difficulty" and "Labor Shortage" Co-exist. In recent years, with the continuous increase in employment positions, the laborers have a larger scope of choices, enterprises are confronted with increasingly greater recruitment difficulties, the high-level technicians are badly needed, and the new-generation laborers become the employment subject, consequently, enterprises generally suffer from "employment difficulty". With the economic development, the laborers generally raise their work standards, have stronger innovation consciousness and flexibility, the management difficulties unprecedentedly increase, all of which influence the enterprise production. Many business rights are ignored, but employee rights are continuously improved. An aquatic product processing enterprise in Rongcheng reflects that heavy losses are caused because the employees are reluctant to work overtime for processing the aquatic products with strict requirements for processing time, but it can do nothing to its employees. In consideration of mobility convenience and insurance expenses, employees are reluctant to sign employment contracts, enterprises have to undertake the liabilities for any labor disputes, and employees can leave at their own will without any limitations, but enterprises are constrained in dismissing employees.

The Lack of Industry Planning Results in Blind Investments of Enterprises, and also Triggers Surplus Productivity Crisis. The market economy is liberal economy, government regulation and industry guidance are still the necessary means of serving the economy in the western countries and China. but it is discovered that difficulties in some industries and lack of industry 
planning are related to poor government guidance. Some enterprises say that the common small and micro businesses don't set the strategic development department and bosses make decisions themselves, as a result, errors are inevitable. Therefore, enterprises should improve their own quality, the industry chambers of commerce, business registration organs, and economic and trade service departments should fully perform the function of guiding the industrial development, so that enterprises can have sufficient knowledge of market saturation level, market development trends, industry policies, industry early-warning and other information, and investors can make their own choices.

Small and Micro Enterprises Have Weak Anti-Risk Capacity, as They are "Small, Scattered and Messy". The majority of small and micro enterprises are small in scale and unstable in operation, firstly, the traditional industries are in the dominant positions, and the high-tech and modern service industries are significantly lacking. Secondly, their organizational degree is low. Small and micro enterprises are family-owned, and many of them don't set modern enterprise systems, have insufficient recognition of centralized and cooperative development and unclear level, and are also in low risk-avoiding ability. Thirdly, their input-output efficiency is low, the R\&D costs of many small and micro enterprises only account for $1 \%$ of the product sales profits. Due to the limited by funds, talents and sci-tech ability levels, their independent innovation levels are obviously low, and are generally characterized by low price, low technology, low profit and low additional value, which restricts the advancement of their investment level to a certain degree. Fourthly, their specialty coordination level is low. Most of leading enterprises realize their supporting cooperation via scattered small and micro enterprises, the supporting enterprises seldom can reach the leading enterprises'level in terms of productivity, equipment, technology and product quality, which hinders the ability improvement of the entire industry; the leading enterprises fail to provide sufficient technologies, talents and funds to supporting enterprises, or show strong driving force.

\section{Successful Experience in "Pursuing Survival and Development" of Small and Micro Businesses}

Cooperative Development, Solve the Issue of "Weak Strength". Small and micro enterprises are small in scale and weak in strength, but if they join up and seek co-development, they can win over certain status and rights in the market competition. Linyi Municipal Wine and Food Chamber of Commerce establishes the United Business Operating Company, all the leaders of the Chamber of Commerce join the Company, elect the board of directors, the board of supervisors, appoint the general manager, and strictly execute the corporative operation. Famous brands in the industry actively seek for cooperation one by one and reach the cooperation intentions.

People First, Solve the Issue of "Labor Shortage". Small and micro businesses provide bad work environments and low wages, and those reduce employees' initiatives and form the current situation of "employees are unwilling to join or stay", therefore, small and micro businesses must start from caring for their employees, establish the long-term mechanism which ensures the synchronous growth of employee incomes and enterprise benefits, attach great importance to the construction of corporate culture, strengthen the skill training,[2] plan the career development paths for employees, and build the good environments which are beneficial to talent development. Rizhao Double-Star Sports and Leisure Clothes Co., Ltd. adopts the method of "ways are always there" by launching subsidiaries in communities and residential areas with surplus labors, and adopts the flexible work system to mitigate the contradiction of labor shortage.

Establish Cooperatives, and Solve the Issue of "Chaotic Development". Small and micro businesses conduct decentralized operations and fight alone, which makes price squeeze easily occur and disturbs the market situation. Cooperatives can better standardize production and operation, and adopt the production model of "uniform management, uniform procurement, uniform processing, and uniform sales", which solve the issue of difficulty to sell tea for tea farmers, and increase their incomes; companies' fund pressure is also alleviated by virtue of members'share capital and some non-urgent funds for raw materials. 
Solve the Issues of "Financing Difficulty" By Virtue of Cooperation with Commerce Chambers and Banks. As they are exposed to great risks and lack mortgage money, and have financing difficulty, small and micro enterprises can effectively release their "financing difficulty" by virtue of the platform of commerce chamber organization. The commerce chambers all over China have done a lot of work in helping small and micro enterprises solve the "financing difficulty". Commerce chambers provide enterprises with the finance guarantee support and banks find high-quality customer groups via commerce chambers, which can not only lower financial risks, but also satisfy the financing demands of small and micro enterprises.

Solve the Issue of "Low Profit" by Lowering Enterprise Costs through Multiple Channels. Small and micro enterprises lower their production operation costs and advance their profitability by improving technological innovation ability, integrating and extending the industry chains, lifting the product additional value, strengthening management, updating equipment, etc. Linyi Zhongxuntong Technology Electronics Co., Ltd. aims at the market frontier, intensify the R\&D degree, improve the product technology content gradually, and realize the enhancement of product additional value. The current product profit growth rate is about $20 \%$.

\section{Suggestions for Promoting Survival and Development of Small and Micro Businesses}

Construct the Investment and Financing Composite System of Government Leadership, Corporate Cooperation and Market Encouragement, and Broaden Financing Methods for Small and Micro Businesses. It is necessary to well apply the guiding function of the state-owned policy-based financing guarantee institutions, against the background of perfecting systems, standardizing steps and conducting effective supervision, allow the institutions to have some bad debts, and fill the blanks in supplying small and micro businesses with popular investment and financing products. It is also necessary to guide banks to intensify thefinancial reform and service degree for small and micro businesses, promote banks to establishdifferent types of business units and professional processing organization, and continue expediting the development of village banks, small-credit companies and financing guarantee companies to fill the blank of financial services.

Expedite the SOE (State-owned Enterprise) Reform, and Expand the Development Space for Private Capital. Monopoly is the obstacle for the market economy reform; if monopoly is not removed, the resource price system is messy, the market development space is fragmented invisibly, consequently, profit solidification and uneven distribution are caused. At present, it is especially essential to deepen the SOE reform with administrative monopoly. The first one is to expedite the promulgation of detailed rules for implementing "36 Tips for private Investment", in order to adjust the economic framework, promote the SOE reform, and expand the private investment scope. The second one is to continue deepening the reforms of financial industry, telecommunications industry, petroleum industry, power industry, railway industry, aviation industry and other monopoly industries, further lower the private capital access threshold, encourage private capital to participate in the production and operation of monopoly industries, and strictly investigate and treat the market access barriers some departments private set.

Strengthen the Classification Guidance, and Energetically Promote the Transformation and Upgrading of Small and Micro Businesses. The Party committees and governments at various levels should treat the different-scale small and micro businesses in different regions and fields with discrimination according to their characteristics of scattered distribution and huge individual differences, corresponding guide them, and energetically promote their transformation and upgrading. The first one is to perfect the industry layout, guide the small and micro businesses to enter themodern agriculture industry, modern service industry and strategic emerging industries. The second one is to expedite therenovation and advancement of traditional manufacturing industry, for the areas with many small and micro supporting businesses, it is necessary to implement the transformation and upgrading of thetraditionalmanufacturingindustry to the transformation development of large-scale leading enterprises and industry clusters, and emphatically encourage the leading enterprises to set industry standards and build brands. 
Standardize the Human Resource Market, and Prevent Brain Drain in Enterprises. Small and micro businesses suffer from serious brain drain, and it greatly influences enterprise production and operation, causes the increases inoperating costs, take away the enterprises' trade secrets and core technologies, and weaken their market competitiveness. Therefore, it is suggested that: one, the department concerned guide enterprises to properly introduce themodern enterprise management systems according to their development stages, to adhere to the philosophy of "people foremost", and to endeavor to establishthe mutual-respect and mutual-trust cooperative relations. Two, enterprise establish effective incentive and constraint mechanisms, make talents form the integration of fundamental interests with enterprises, provide employees with good work and life environments, satisfy their basic life demands, conductthe human-based management, strengthen the technical training and quality cultivation, and intensify employees' sense of belonging from various aspects. Three, enterprises intensify the degree of liquidated damages. Enterprises sign explicit contracts with employees to improve the legal effect, prevent the random brain drain, perfect the supervision policies, and strengthenthe supervision and prevention of malicious brain drain. Four, the talent resource market be standardized for providing enterprises with more high-quality ad virtuous talent resources. The platform of introducing well-educated and high-skilled talents be established in order to provide technicalsupport for enterprise development.

Implement More Flexible Tax and Employment Systems, and Create Relaxed Environment for the Development of Small and Micro Enterprises. Under the current situation where the small and micro enterprises are faced with increase in cost pressure and decrease in operational profit, it is suggested firstly that small and micro enterprises implement light tax policies, promote the structural tax reduction step by step, and expedite the design of more reasonable tax preferential policies. For example, implementing"exemption from income taxation for first two years, reduction half for next three years" for fixed taxes and income tax for small and micro enterprises, if it is difficult to promote the policy in a short time, if appropriate, making experiments within a certain period in some regions and effectively reducing their business burden; increasing thevalue-added tax and business tax threshold for small and micro enterprises, and accelerating to promote the change from business tax to value-added tax in the service industry to larger service industry range. It is suggested secondly that small and micro enterprises implement flexible employment systems. Under thesituation where an employer and employee discuss, it is necessary to simplify the labor employment process of small and micro enterprises, on the basis of abiding by the laborers' intentions, small and micro enterprises are allowed to flexibly select employees and make their salary levels fluctuate within a certain degree of the minimum salary guideline.

Establish the Specialized Statistical Systems for Small and Micro Enterprises to Dynamically Track Their Development Situations. Small and micro enterprises are the most fundamental subject in the market, they are highly sensitive and can directly reflect the market operation situation and economicdynamic changes. Only when the actual development situations of small and micro enterprises are mastered, can the actual economic operation situation be objectively and truthfully reflected. Therefore, it is necessary to set a specialized statisticalsystem for small and micro enterprises. Small and micro enterprises in different fields are selected to establish the sample database for forming the basis and ground for the dynamic operation status of small and micro enterprises. On the premise, small and micro enterprisesestablish the development indexes of enterprise operation, market, cost, fund, input and benefit to investigate the sample enterprises' macro-economic sensation, and small and micro enterprises establish the development indexes to dynamically reflect their operation states and comprehensive situations by judging the industry operation and their own production operation situations and adopting predicted data[3].

Give Full Play to the Advantages and Roles of Association of Industry and Commerce as well as Commerce Chambers in Promoting the Healthy Development of Small and Micro Enterprises. According to the spirit of The Opinions from the State Council on Strengthening and Improving the Work of the Associations of Industry and Commerce under New Situations, it is necessary to intensify and carry out theeconomic function of associations of industry and commerce, take associations of industry and commerce in the leadership formation and coordination mechanism 
for promoting the development of small and micro enterprises, bring the support the development of small and micro enterprises into the work system of associations of industry and commerce, give full play to the active role of associations of industry and commerce in the reform and development of industrial associations and commerce chambers, and take the intensifying construction of industrial associations and commerce chambers as the important platform and grasp for serving small and micro enterprises. It is necessary to innovate the social management thinking, speed up the orderly transfer of government functions, actively cultivate the commerce chamber organizations with the Chinese characteristics, energetically develop various commerce chambers for serving small and micro enterprises, form the commerce chamber organization system with explicit layers and reasonable specialization, fully exercise the standardization, guidance and service functions of industrial commerce chambers, and actively promote the orderly development of small and micro enterprises. It is necessary to perfect the industry self-discipline, lift the service degree and prevent chaotic competition and blind development by improving the operation construction of industrial commerce chambers, give full play to the role of prior to carry and try of commerce chambers in providing mutual help to small and micro cross-strait enterprises, quicken the exchange and cooperation among the cross-strait commerce chambers and enterprises by taking the opportunity of ECFA signing, and promote the exchange and cooperation among small and micro cross-strait enterprises in terms of experience, technologies and personnel. At the same time, it is also necessary to give full play to the important role of industrial associations and commerce chambers in leading teams. The small and micro enterprise investors are an important force of the non-public economy individuals, the Party committees and governments at various levels should give full play to the advantages of industrial associations and commerce chambers in directly facing and contacting enterprises, and do a good job of ideology and politics guidance for the group, cultivate an outstanding builder team which actively participates in social construction and have the courage to undertake social responsibilities and improve livelihood, build the good image of small and micro enterprises, and then promote the scientific development and stability of the society.

\section{References}

[1] X.S.Li., Analysis on the Countermeasures to Alleviate the Financing Difficulties of Small and Micro Enterprises. Economic Research Guide, 2(1), pp. 118-119, 2013.

[2] X. Zhang.,Construction of the Supporting System for the Development of Small and Micro Enterprises. Journal of Fujian Institute ofSocialism, 6(1), pp. 104-107, 2014.

[3] J. Wang.,Analysis on Financing Problems of Small and Micro Enterprises in China. Investment and Cooperation , 4(1), pp. 174-174, 2014. 